電気油圧駆動による柔軟マルチボディシステムの動的シミュレーション*

南條孝夫 ${ }^{* 1}$ ，今西悦二郎 ${ }^{* 1}$

\title{
Dynamic Simulation of Flexible Multibody System with Electro-Hydraulic Drive
}

\author{
Takao NANJO*1 and Etsujiro IMANISHI \\ ${ }^{* 1}$ KOBE STEEL, Ltd., Mechanical Engineering Research Laboratory \\ Takatsuka-dai 1-5-5, Nishi-ku, Kobe, 651-2271 Japan
}

The modeling for the total system of the hybrid excavator is presented by introducing the flexible multibody system with the electric-hydraulic drive system, which consists of the engine, the battery system, the generator, and actuators driven by the electric-hydraulic power train system. The attachment and the hydraulic system of the hybrid excavator are formulated by introducing the nonlinear finite element analysis. The power electronic system, which includes the battery system, the generator, the convertor, the motor, and the controller, is modeled by employing the analogy of the hydraulic circuits. Firstly, the dynamic simulations are performed by using this model in the boom system for the operability design. It is demonstrated that the vibration control is effective to reduce the residual vibration of the boom. Secondly, the dynamic simulations are carried out for the energy saving performances of the hybrid excavator, which are conducted on the actual operation such as the excavating, and so on. It is verified that the simulation results for both the power and the energy saving performance fairly agree with the experimental ones. The energy saving effects of the hybrid excavator can be expected to be more than $40 \%$ for the actual operation comparing with the conventional one.

Key Words : Multibody Dynamics, Oil and Air Hydraulics, Modeling, Construction Machinery, Simulation, Power Electronics, Hybrid System, Hydraulic Excavator

\section{1. 緒言}

近年，地球温暖化防止や経済性などの観点から，油圧ショベルの省エネルギ化の要求はますます高まりつつあ る. 油圧ショベルの大幅な省エネルギを図るためには，油圧動力配分時に生じる損失を低減する必要があり，そ の解決策として電力制御による動力配分，およびエンジン動力の平準化から，エンジンとバッテリシステムから なるハイブリッドシステム(1)(2)の適用が有効と考えられる. 著者らは電動油圧システム，およびハイブリッド動 力源システムからなるハイブリッドショベルの開発を行ってきた．本システムは，各アクチュエータへの動力配 分をインバータなどのパワーエレクトロニクス機器を用いた電力配分制御によって行うため, 油圧動力を配分制 御するときに発生する損失を低減することができ，省エネルギ化を図ることができる.

一方，柔軟マルチボディダイナミクスに関する研究は，これまでに非線形有限要素モデルなどを基礎とした多 くの研究 ${ }^{(3) \sim(6)}$ がなされている. 特にはりに関しては, 浮動基準座標, 絶対節点座標などによって変形挙動を記述 するモデルが提案されている．また，自動車，鉄道車両などの分野においては，柔軟マルチボディシステムや油 圧制御システム用市販ソフトが数多く開発されてきている．著者らも，これまでに油圧制御システムを含む柔軟 リンクシステムの解析コードSINDYS を開発し, 建設機械の動的シミュレーションを数多く実施してきた ${ }^{(7),(8)}$. ところが，ハイブリッドショベルはパワーエレクトロニクス機器を用いた動力源システムから構成されており， 解析によってハイブリッドショベル全体の性能評価を行うためには，パワーエレクトロニクスシステム，油圧シ

* 原稿受付 2011 年 4 月 23 日

*1 正員, (株) 神戸製鋼所 機械研究所（一 $651-2271$ 兵庫県神戸市西区高塚台 1-5-5）

E-mail: nanjo.takao@kobelco.com 
ステム，およびアタッチメントのリンクシステムからなるトータルシステムの動的シミュレーション技術が必要 である．自動車の分野では，ハイブリッドシステムに対するシミュレーションが行われている ${ }^{(9)}$ が，パワーエレ クトロニクスシステム, 油圧システム, およびリンクシステム全てのダイナミクスを考慮したシミュレーションは 行われていない. また, 世の中の市販ソフトにおいて, 同様なシミュレーションが可能であると言われているが， その多くは，パワーエレクトロニクスシステム，油圧システム，およびリンクシステムをそれぞれ独立したソフ トとして開発し，時間ステップごとに状態量を交換して全体のシステムシミュレーションを行う方法が採用され ている．そのため，機器の非線形性が強いハイブリッドショベルでは，数值的に安定したシミュレーションを行 うことが難しいのが現状であった.

そこで，ハイブリッド動力源を構成する発電機，バッテリ，コンバータなどのエレクトロニクス機器，アクチ ユエータシステムを構成する電動油圧機器，およびアタッチメントのリンクシステムからなるトータルシステム をモデル化したハイブリッドショベルの動的シミュレーション技術を開発した．本手法の特徴は，ハイブリッド ショベル全体のダイナミクス運動方程式を 1 つのソフト内（解析コード : SINDYS）で構築し，時間積分法として 陰解法を用いた数值解析を行ったことにあり, それによって数值解析的な安定性を向上させ, 実用的なシミュレ ーション技術を開発したことである。このシミュレーション技術を用いてハイブリッドショベルの挙動および然 費のシミュレーションを行い, システムの性能評価を行うとともに，省エネ性能について実機実測結果と比較す ることによって，その有効性を検証した.

\section{2. 電気油圧駆動システムと柔軟リンクステムの連成解析理論}

\section{$2 \cdot 1$ 運動方程式}

非線形動的解析における運動方程式は，一般に

$$
\mathbf{g}_{m}+\mathbf{g}_{c}+\mathbf{g}_{k}=\mathbf{f}
$$

のように記述できる.ここで, $\mathbf{g}_{m}, \mathbf{g}_{c}, \mathbf{g}_{k}, \mathbf{f}$ は慣性力, 減衰力, 弾性力, および外力である.ここでは, 油圧駆 動システムと柔軟リンクシステムが連成するシステムを時刻 $t_{n}$ で線形化することによって, 次式のような MCK 形の非線形運動方程式に記述する.

$$
\mathbf{M} \ddot{\mathbf{q}}_{n+1}+\mathbf{C} \dot{\mathbf{q}}_{n+1}+\mathbf{K} \mathbf{q}_{n+1}=\mathbf{f}_{n+1}-\overline{\mathbf{f}}_{n}
$$

ここで, $\mathbf{q}_{n+1}$ はリンクシステムでは時刻 $t_{n+1}$ における変位, 油圧システムでは流量積, 電気回路では電荷などの状 態量を表すべクトルである. $\mathbf{M}, \mathbf{C}, \mathbf{K}$ は時刻 $t_{n}$ で線形化された質量, 減衰, 剛性マトリックスであり, $\mathbf{f}_{n+1}$ は時刻 $t_{n+1}$ における外力である． $\overline{\mathbf{f}}_{n}$ は非線形要素力を各時間ステップで線形化することによる補正外力である.

\section{$2 \cdot 2$ 柔軟リンクシステムの解析理論 ${ }^{(8)}$}

物体が空間内を大きく運動する場合, 要素の幾何学的非線形性を考慮する必要がある. このような非線形要素 の例として, 3 次元空間で大変位するはり要素を取り上げる. 図 1 に示すように, 時刻 $t_{n}$ の先行要素の両端 $A, B$ における座標系を $\boldsymbol{\omega}_{A}, \boldsymbol{\omega}_{B}$ とし, 時刻 $t_{n+1}$ の節点変位に伴って回転する座標系を $\boldsymbol{\omega}_{A}^{\prime}, \boldsymbol{\omega}_{B}^{\prime}$ とし, さらに $\boldsymbol{\omega}_{A}^{\prime}, \boldsymbol{\omega}_{B}^{\prime}$ は任意 の方向を向いているため第 3 軸が共通な要素座標系 $\boldsymbol{\omega}_{A}^{\prime \prime}, \boldsymbol{\omega}_{B}^{\prime \prime}$, および各軸とも共通な要素座標系 $\widetilde{\boldsymbol{\omega}}_{A}\left(=\widetilde{\boldsymbol{\omega}}_{B}\right)$ を導入 する. 弾性変形による回転変形ベクトルは， $\widetilde{\boldsymbol{\omega}}_{A}$ から $\boldsymbol{\omega}_{A}^{\prime}$ への変換マトリックスから得られる. 回転変形ベクトル を変位の 2 次項まで考慮してポテンシャルエネルギを求め, 変位に対して 2 回微分寸ることによって幾何剛性マ 
トリックス $\mathbf{k}_{g}^{\prime}$ を求める. また, 通常の微小変形理論における要素剛性マトリックス $\mathbf{k}_{0}^{\prime}$ を用いると, 時刻 $t_{n+1}$ にお いて要素座標系 $\tilde{\boldsymbol{\omega}}_{A}$ における要素弹性力 $\mathbf{g}_{k}^{\prime}$ は次式で表される.

$$
\mathbf{g}_{k}^{\prime}=\mathbf{g}_{k, n}^{\prime}+\left(\mathbf{k}_{0}^{\prime}+\mathbf{k}_{g}^{\prime}\right) \Delta \mathbf{q}^{\prime}
$$

ここで, $\Delta \mathbf{q}^{\prime}=\mathbf{q}_{n+1}^{\prime}-\mathbf{q}_{n}^{\prime}$ であり，右上添字＇は要素座標系 $\tilde{\boldsymbol{\omega}}_{A}$ で表されていることを示す. 式(3)を全体座標系 に座標変換すると次式の要素弾性力が得られる.

$$
\mathbf{g}_{k}=\mathbf{g}_{k, n}+\mathbf{k} \Delta \mathbf{q}
$$

ここで,

$$
\begin{aligned}
& \mathbf{k}=\mathbf{T}^{T}\left(\mathbf{k}_{0}^{\prime}+\mathbf{k}_{g}^{\prime}\right) \mathbf{T} \\
& \mathbf{g}_{k, n}=\mathbf{T}^{T} \mathbf{g}_{k, n}^{\prime}
\end{aligned}
$$

である． $\mathbf{T}$ は全体座標系から $\tilde{\boldsymbol{\omega}}_{A}$ への座標変換マトリックスでる. 補正外力

$$
\overline{\mathbf{f}}_{\mathrm{n}}=\mathbf{g}_{k, n}-\mathbf{k} \mathbf{q}_{n}
$$

を導入することによって式(3)を全変位系に変換し運動方程式(2)に組み込む.

要素質量マトリックスは，質量マトリックスを次式のように，全体マトリックスに座標変換することによって 得られる.

$$
\mathbf{m}=\mathbf{T}^{T} \mathbf{m}_{0}^{\prime} \mathbf{T}
$$

要素減衰マトリックスは，要素剛性マトリックスを用いた比例減衰

$$
\mathbf{c}=\beta \mathbf{k}
$$

を用いる. 要素ごとに導かれたマトリックスを重㸚わせることによって全体システムの質量, 減衰, 剛性マト リックス，および補正外力が得られる.
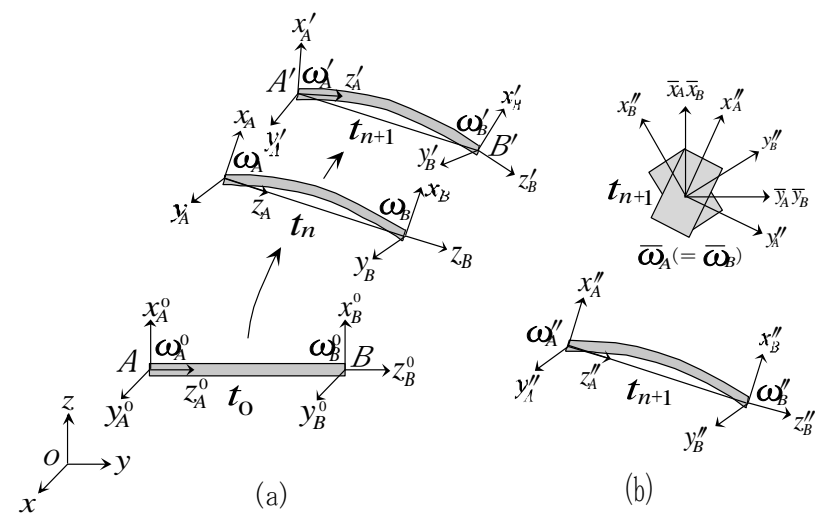

Fig.1 Element coordinate systems of beam element

\section{$2 \cdot 3$ 油圧駆動システムの解析理論 ${ }^{(7)}$}

油圧駆動システムとリンクシステムの連成解析のための基本要素であるシリンダ要素を考える. ポートからの 作動油の流入・流出によってストロークが伸縮し, 部材端における負荷に応じてシリンダ内部に圧力が生じるシ リンダ要素を考える. 要素座標系において流量積（体積流量の積分值）の増分 $\Delta \mathbf{q}^{\prime}$ と圧力の増分 $\Delta \mathbf{p}^{\prime}$ の関係式を求 
め, 全体座標系での節点変位増分 $\Delta \mathbf{q}_{A}, \Delta \mathbf{q}_{B}$, ポート流量積増分 $\Delta q_{\mathrm{p}}$ と, 節点力増分 $\Delta \mathbf{f}_{A}, \Delta \mathbf{f}_{B}$, ポート圧力増分 $\Delta p$ の関係 式に座標変換すると次式が得られる.

$$
\left\{\begin{array}{c}
\Delta \mathbf{f}_{A} \\
\Delta \mathbf{f}_{B} \\
\Delta p
\end{array}\right\}=\left[\begin{array}{ccc}
(\mathbf{A}+\mathbf{W}) & -(\mathbf{A}+\mathbf{W}) & \lambda A_{c} k \mathbf{x} \\
-(\mathbf{A}+\mathbf{W}) & (\mathbf{A}+\mathbf{W}) & -\lambda A_{c} k \mathbf{x} \\
\lambda A_{c} k \mathbf{x}^{\mathrm{T}} & -\lambda A_{c} k \mathbf{x}^{\mathrm{T}} & \lambda^{2} k
\end{array}\right]\left\{\begin{array}{c}
\Delta \mathbf{q}_{A} \\
\Delta \mathbf{q}_{B} \\
\Delta q_{p}
\end{array}\right\}
$$

ここで, $\mathbf{A}=k A_{\mathrm{c}}^{2} \mathbf{x x}^{T}, \quad \mathbf{W}=p_{c} A_{c}\left(\mathbf{I}-\mathbf{x} \mathbf{x}^{T}\right) / l_{\mathrm{t}}, \quad k=\kappa / V_{c}, \mathbf{x}$ は方向余弦ベクトル， $\mathbf{I}$ は単位マトリックス, $A_{c}$ はシリ ンダ断面積， $V_{c}$ はシリンダ内作動油体積， $\lambda$ は流入方向を表す係数， $p_{c}$ はシリンダ内圧である. 式(10) は油圧駆 動システムの作動油流量積とリンクシステムの節点変位が連成しており, 連成解析が可能となる. 上式は, ヘッ ド側だけのつり合い式であるが，ロッド側も同様に考えることができる，その他，質量，比例減衰，ストローク エンドのストッパ, 摩擦抵抗などを考慮している.

\section{$2 \cdot 4$ パワーエレクトロニクスシステムの解析理論}

ハイブリッド動力源システムを構成するパワーエレクトロニクス機器として, 発電機, バッテリ, キャパシタ, コンバータ, 電動モータがあり, それらのモデル化を考える.

発電機は永久磁石式 3 相同期発電機を対象とし, d-q 座標で表された等価な直流回路のうち, d 軸電流を零とす る制御を行うことを考え，q軸の等価回路をモデル化する. 発電機の状態量として，q軸の等価回路の電荷 $q_{g}$, および発電機回転角 $\theta_{g}$ の 2 自由度とすると, 電気回路方程式および運動方程式は次式で与えられる.

$$
\begin{aligned}
& L_{g} \ddot{q}_{g}+R_{g} \dot{q}_{g}-K_{e} \dot{\theta}_{g}=-V_{g} \\
& J_{g} \ddot{\theta}_{g}+T_{\eta}\left(\dot{\theta}_{g}\right)+K_{t} \dot{q}_{g}=T_{g}
\end{aligned}
$$

ここで， $L_{g}$ は発電機インダクタンス， $R_{g}$ は発電機内部抵抗， $J_{g}$ は回転軸慣性モーメント， $T_{\eta}\left(\dot{\theta}_{g}\right)$ は機械損失トル ク, $K_{t}$ はトルク定数, $K_{e}$ は起電力定数, $V_{g}$ は発電機コンバータ制御電圧, $T_{g}$ は発電機負荷トルクである. $\mathrm{q}$ 軸の 等価回路を図 2 に示す.

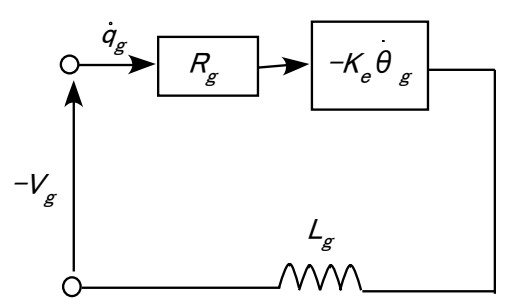

Fig.2 Equivalent circuit of d-axis in generator model

バッテリは，温度特性を除くと充放電の使用範囲内で内部抵抗を一定とみなすことができ，その場合には次式 の電気回路方程式が得られる.

$$
R_{b} \dot{q}_{b}+V_{b}\left(q_{b}\right)=V_{\text {out }}
$$


ここで， $R_{b}$ はバッテリ内部抵抗， $V_{b}\left(q_{b}\right)$ はバッテリ内部電圧， $V_{\text {out }}$ は出力電圧， $q_{b}$ はバッテリ電荷である．キャパ シタに関しても式(13)と同様な関係が成り立つ.

動力源システムにおける電力システムでは，パワーエレクトロニクス機器を電気配線によって結合しており， 分岐などの電気回路をモデル化するための電気結合要素を考える. 図 3 (a) に示す 3 分岐配線の場合には, 各節点 の状態量として電荷 $\mathbf{q}_{e}=\left\{q_{1} q_{2} q_{3}\right\}^{T}$ をとり, 節点電圧を $\mathbf{V}_{e}=\left\{V_{1} V_{2} V_{3}^{T}\right\}^{T}$ とし, 配線内部の電圧は一定であると考えると次 式の電圧方程式が得られる.

$$
\begin{aligned}
\mathbf{V}_{e} & =\mathbf{K}_{w} \mathbf{q}_{e} \\
\mathbf{K}_{w} & =K_{w}\left[\begin{array}{ccc}
\lambda_{1}^{2} & \lambda_{1} \lambda_{2} & \lambda_{1} \lambda_{3} \\
\lambda_{1} \lambda_{2} & \lambda_{2}^{2} & \lambda_{2} \lambda_{3} \\
\lambda_{1} \lambda_{3} & \lambda_{2} \lambda_{3} & \lambda_{3}^{2}
\end{array}\right]
\end{aligned}
$$

ここで， $K_{w}=1 / C_{w}$ であり， $C_{w}$ は配線部の電気容量である. また, $\lambda_{i}(i=1,2,3)$ は方向を示寸座標変換係数であり, 内 向きが 1 , 外向きが-1 である. なお，配線部の電気抵抗とインダクタンスは，無視できるものとして省略した.

電力システムでは, 発電機, バッテリ, キャパシタの各機器の電力を制御するためにコンバータを用いる.コ ンバータはスイッチングにより電力制御を行うが，ここでは電力変換が理想的に行われると考え，電力を一定に 保ちながらコンバータ部の電流を変化させるモデル化を考える. 図 $3(b)$ に示寸 2 節点電気結合要素において, 節 点 2 がコンバータ部とする. コンバータ部の電圧 $V_{2}^{\prime}$ を $\lambda_{c}$ 倍する場合には $V_{2}=\lambda_{c} V_{2}^{\prime}$ であり, 電力一定の条件からコ ンバータ部の電荷は $q_{2}^{\prime}=\lambda_{c} q_{2}$ となる. 電流の方向を考慮すると座標変換係数は $\lambda_{1}=1, \lambda_{2}=-\lambda_{c}$ であり, 式(14)の電圧 方程式は次式のようになる.

$$
\left\{\begin{array}{l}
V_{1} \\
V_{2}
\end{array}\right\}=K_{w}\left[\begin{array}{rr}
1 & -\lambda_{c} \\
-\lambda_{c} & \lambda_{c}^{2}
\end{array}\right]\left\{\begin{array}{l}
q_{1} \\
q_{2}
\end{array}\right\}
$$

図 4 に示寸コンバータコントローラでは, コンバータ電流を検出し, PI 制御することによって電力変換を行う. そのモデル図を図 4 に示す. 電力変換指令に基づいて $\lambda_{c}$ を決定し, 式(16)における $\lambda_{c}$ を変化させることによって 計算を行う.

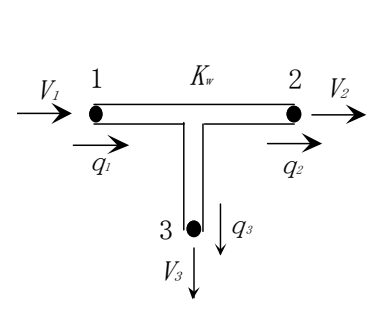

(a) 3-ports element

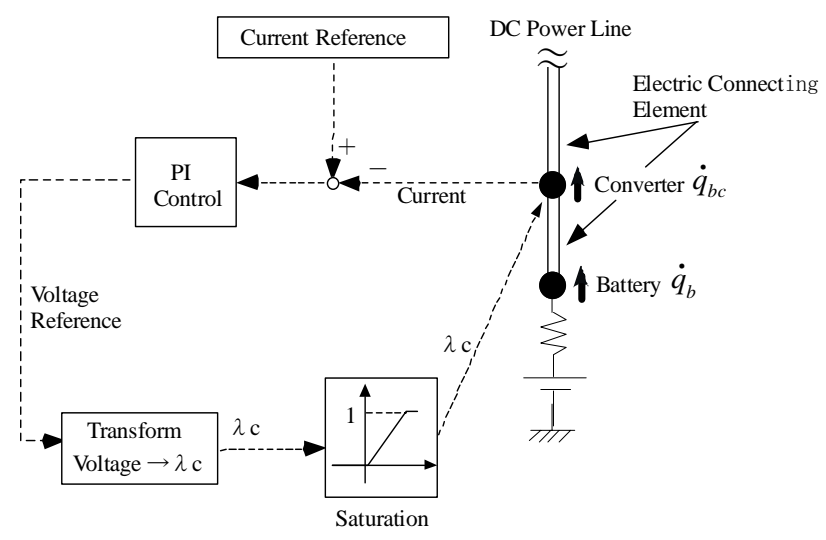

Fig.4 Converter control system model

\section{$2 \cdot 5$ エンジンシステムの解析理論}

エンジンは電子ガバナ付きディーゼルエンジンを対象とする. 電子ガバナ部はエンジン回転数制御を行った信 号からラック位置, およびその位置での駆動トルクを算出し, 次式に用いて回転数を計算する.

$$
J_{e} \ddot{\theta}_{e}+R_{e} \dot{\theta}_{e}=T_{e}\left(\dot{\theta}_{e}, x_{r}\right)-T_{g}
$$


ここで， $J_{e}$ はエンジン慣性モーメント， $R_{e}$ はエンジン内部抵抗， $T_{e}\left(\dot{\theta}_{e}, x_{r}\right)$ は駆動トルク， $x_{r}$ は燃料噴射量調整位置 である. 燃料消費量は，エンジン回転数および出力トルクの関数として燃料消費量マップから算出する.

\section{3. ハイブリッドショベルのシステム構成とモデル化}

\section{$3 \cdot 1$ ハイブリッドシステムの概要}

ハイブリッドショベルの外観図およびシステム構成をそれぞれ図 5, 6 に示す．ショベルのアクチュエータは, アタッチメントを構成するブーム，アーム，バケット，上部構造物の旋回，および左右のクローラ走行の 6 軸か ら構成されている，各アクチュエータは，基本的には独立なシステムによって構成する．そのため，従来の油圧 ショベルにおいて発生していた油圧配分損失を低減させることができる．また，動力源はエンジン動力の平準化 のためにエンジンとバッテリ・キャパシタからなるシリーズ方式のハイブリッド動力源システムである.

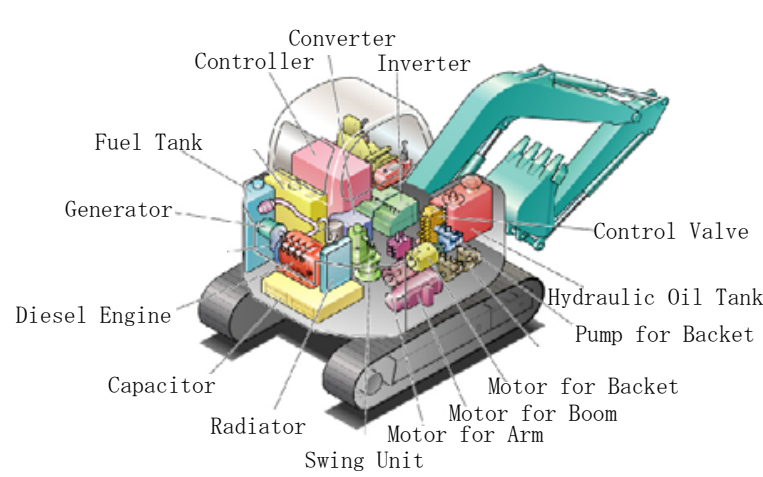

Fig.5 Conceptual scheme of hybrid excavator

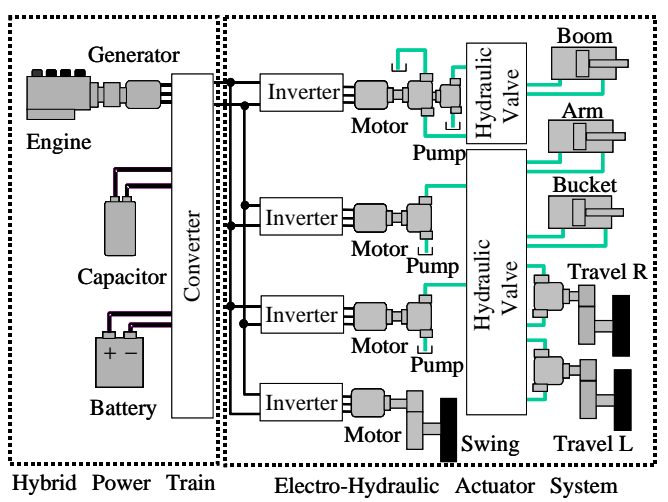

Fig.6 System diagram of hybrid excavator

\section{$3 \cdot 2$ 動力源システム}

動力源システムはシリーズ方式としているため, ハイブリッド動力源から各アクチュエータへの動力は, 直流 母線によって電力供給される. そのため, 各アクチュエータの消費動力に応じて, 電力が供給され, 各アクチュ エータに配分される. アクチュエータの消費動力に対して動力源からの電力を安定して供給するために, 直流母 線の電圧を一定に保つ制御（直流母線電圧制御）を行う。これは母線の電圧をフィードバック制御することによ って行う．キャパシタは回生電力の充電を行うことを目的としており，放電動作においては発電機やバッテリよ り優先させ，常に回生電力を受け入れ可能な状態にする. 図 7 に動力源の制御モデルを示すが，発電機，バッテ リ，キャパシタの電力制御は，コントローラでの電力指令に基づき，各要素の電流をフィードバックしながら座 標変換コード入を可変に制御することによって電力制御を実現させる.

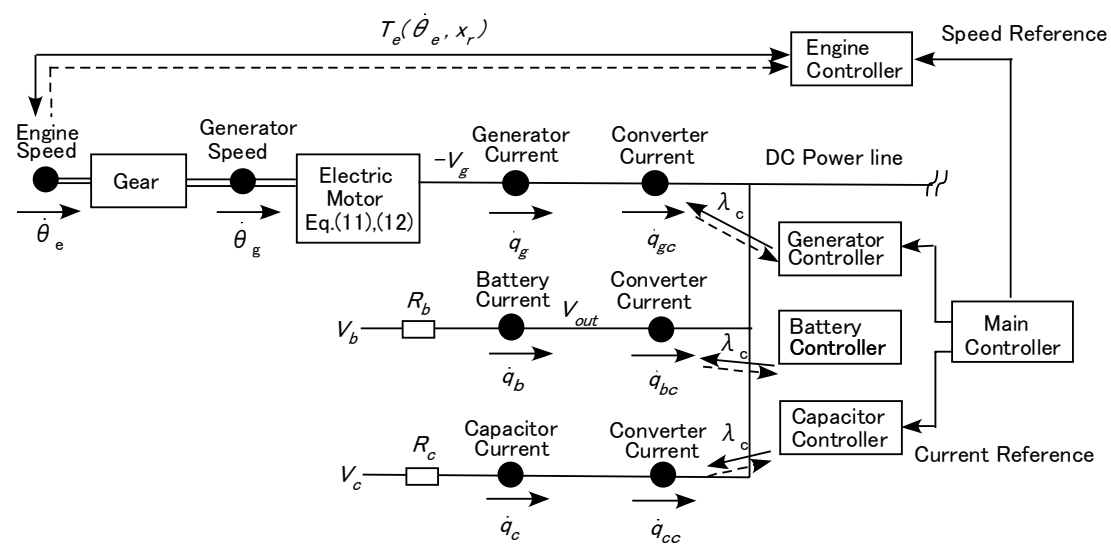

Fig.7 Power train system model 


\section{$3 \cdot 3$ アクチュエータシステム}

アクチュエータシステムは，ブームシステム，アームーバケットー走行システム，および旋回システムからな る.ブームシステムは，アタッチメントの自重を保持しており，ブーム上昇時に蓄積した位置エネルギを回生す るため，電動機，両回転油圧ポンプ，制御弁を用いたクローズドな電動油圧システムとしている．ブーム下げ操 作時に発生するブームヘッド側の油圧動力を両回転油圧ポンプに作用させ，その動力によって電動機に回生電力 を発生させる. 発生した回生電力は，キャパシタおよびバッテリに充電される．アーム・バケットシステムは, 電動機，片回転ポンプ，方向制御弁などを用いたオープンシステムである．旋回システムは，回転運動であるこ とから油圧は用いず，電動機駆動システムとしている．走行システムは，アーム・バケットの油圧源を用いた電 動油圧駆動システムとしている.

図 8 にブームシステムのアクチュエータモデルを示し, 図 9 に駆動電動機の制御モデルを示す.電動機の制御 も基本的には発電機と同じであるが，速度フィードバックおよび電流フィードバックを行い，最終的に直流母線 に対する座標変換係数入を可変にすることにより，速度制御を実現させる．また，アタッチメントの機構系リン クシステムおよび上部旋回体は, 図 10 に示すように, 各部位を大変位はり要素を用いてモデル化し, 重量は各部 材の重量重心位置の集中質量として定義するとともに，ピン結合部分はピン軸周りの回転自由度を各部財座標系 で定義し，それらを独立に扱う。
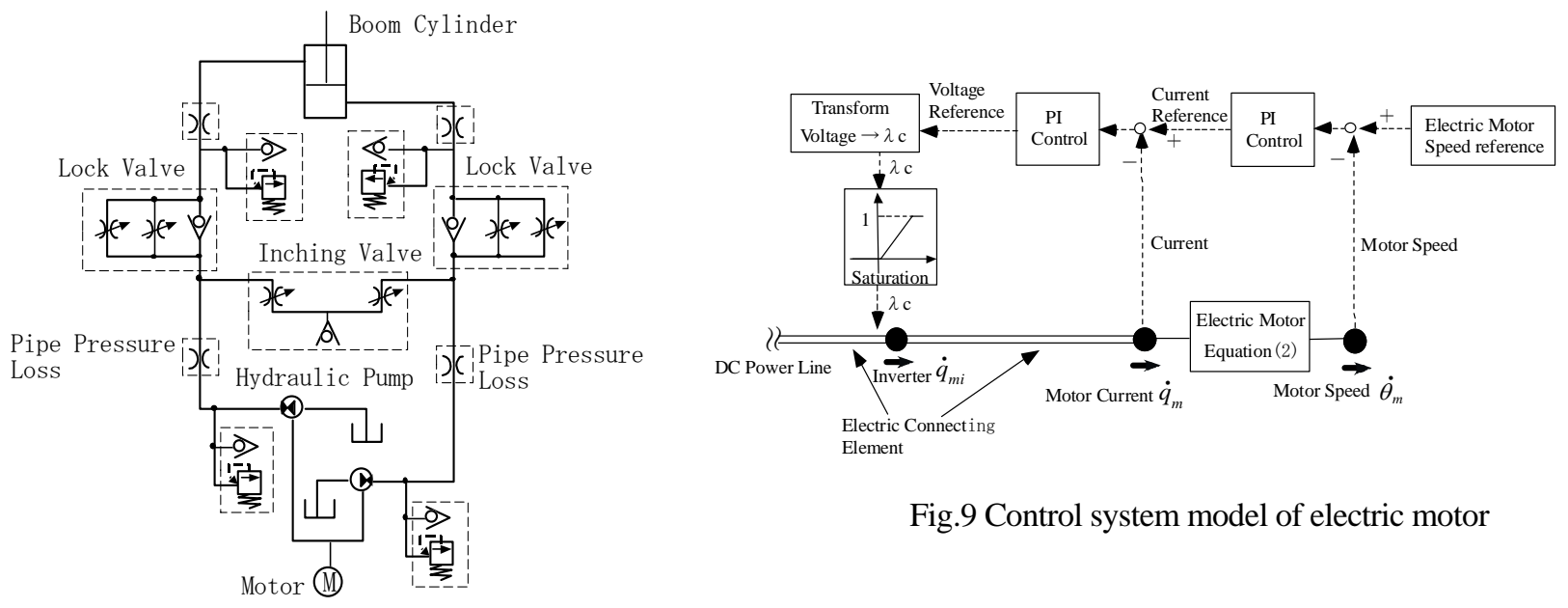

Fig.9 Control system model of electric motor

Fig.8 Boom system model

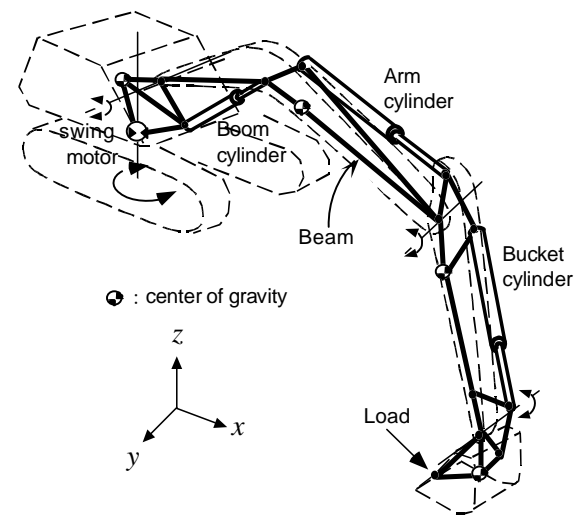

Fig.10 Linkage system model of hybrid excavator

\section{$3 \cdot 4$ システム方程式とフローチャート}

ハイブリッドショベルの数式モデルは, リンクシステム, 油圧システム, パワーエレクトロニクスシステム, およびエンジンシステムの要素ごとに生成された方程式を有限要素法的に組み合わせ, 式(2)のシステム運動方程 式を構築する.システム構成図は図 5 に示したものを用いており,このときの数式モデルの概念図を図 11 に示寸. 


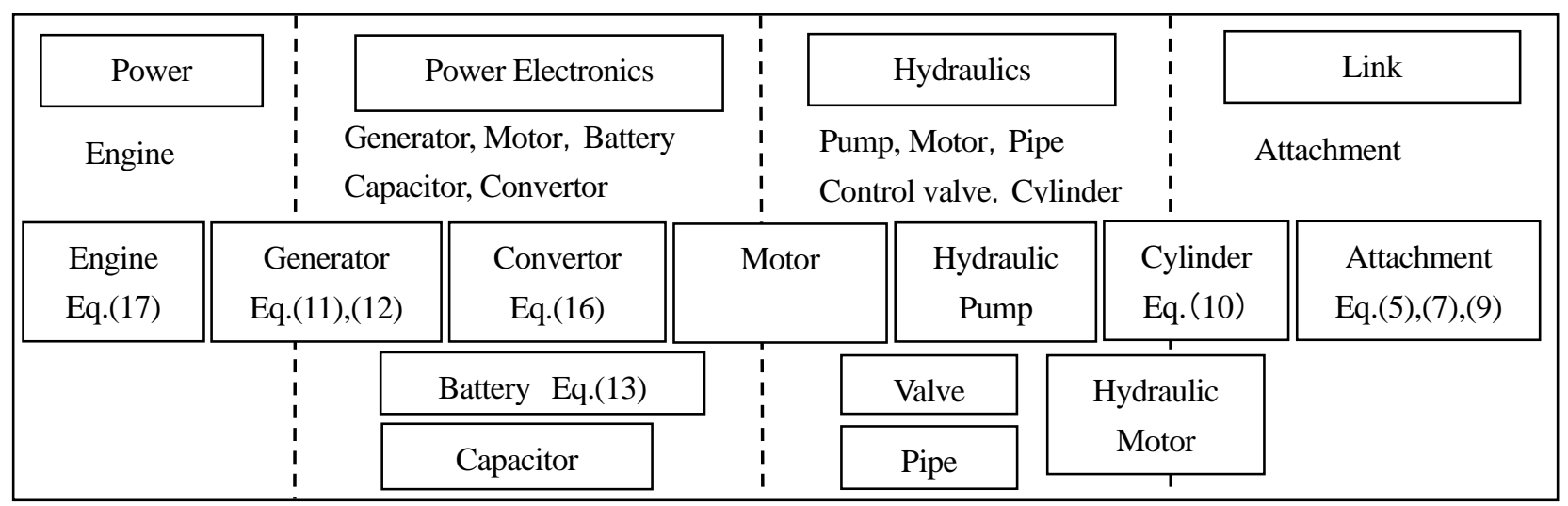

Fig.11 Conceptual mathematics model of hybrid system

また, システムシミュレーションのフローチャートを図 12 に示す. 各要素において生成された MCKマトリック ス，および動力源システム，アクチュエータシステムにおけるシステム指令を，システム方程式の MCK マトリ ックスおよび外力項に組み込む. その後, ニューマーク $\beta$ 法およびニュートン法を用いてシステム運動方程式を 時間ステップごとに解き，シミュレーションを実行する．本手法では，時間積分法としてニューマーク $\beta$ 法，収 束計算法としてニュートン法を用いることによって数值解析的な安定性を確保することができる. なお，市販ソ フトでは，リンクシステム，油圧システム，およびパワーエレクトロニクス機器をそれぞれ独立したソフトとし て開発し, 時間ステップごとに状態量を交換して全体のシステムシミュレーションを行う方法が採用されている. そのため, 機器の非線形性が強いハイブリッドショベルでは, 安定したシミュレーションを行うことが難しい.

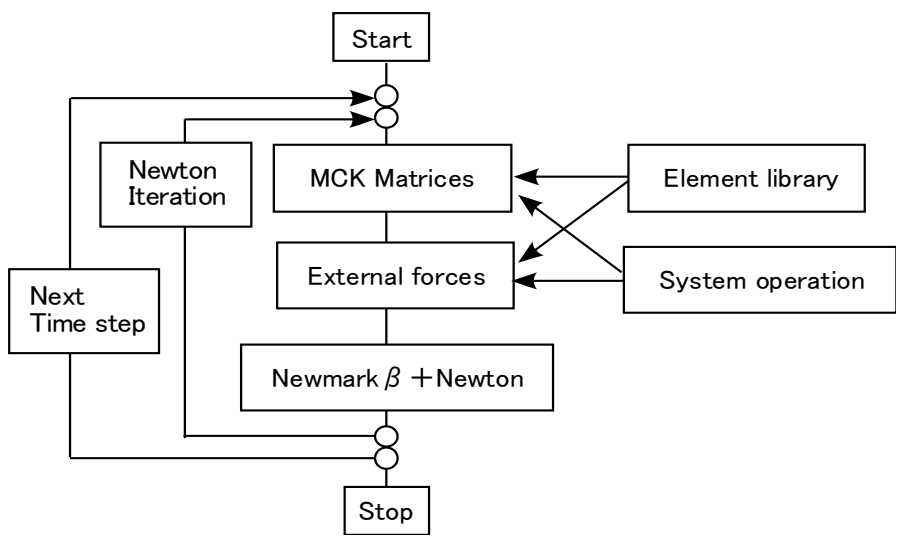

Fig.12 Flow chart of system simulation

\section{4. 性能評価解析および精度検証}

ハイブリッドシステムのトータルシミュレーションモデルを用いて，各種の性能評価解析を行った。また，八 イブリッドショベルの性能実証機を製作し，実機試験により，従来機との性能比較を行っている.

以下では，性能評価の例として，ブームアクチュエータシステムの性能と，代表的な油圧ショベルの作業パタ ーンについて然費性能を解析で評価し，実機での計測により精度検証を行った結果を述べる.

\section{1 ブームシステムの性能評価}

ブームシステムは, 図 7 に示すように電動機により駆動される油圧ポンプで圧油を吐出し, 油圧モータでシリ ンダから排出される圧油を受けるクローズドシステムとなっている．通常の油圧ショベルでは，ブーム下げ時の アタッチメントの位置エネルギを排出側の油圧バルブの絞りにより熱として捨てているが，このシステムでは排 
出側の圧油の動力を油圧モータを介して電動機に伝え，エネルギを回生するシステムとなっている．また，アタ ッチメントの慣性力の影響で振動しやすい系であるので，振動低減のため電動機の回転数制御により，振動抑制 を行っている.この制御も含めて, ブーム操作時のシリンダ挙動および消費パワーを解析により評価した. 図 10 にブーム上げ下げ操作時の挙動および動力解析評価と実機試験での性能比較を示寸．図 $13(\mathrm{a})$ ，(b) はそれぞれ駆動 電動機の回転数およびシリンダの速度を示している. 図 13 (c), (d) は駆動電動機およびシリンダの動力を示している. 前半部分のブーム上げ操作（力行）時には動力が正の值となり，電力を消費しているが，後半部分のブーム下げ 操作時には動力が負となり，エネルギ回生が行われていることがわかる．いずれの実測結果もシミュレーション モデルとよく一致した結果となっており，挙動の評価においても動力評価においてもシミュレーションモデルが 妥当であるといえる．これによって，本手法によるハイブリッドショベルの動的シミュレーション技術は，数值解析 的な安定性が確保されており，実用的な解析技術であると言える. なお，図 13 以降の縦軸は，社内基淮に基づいて正規化 している.

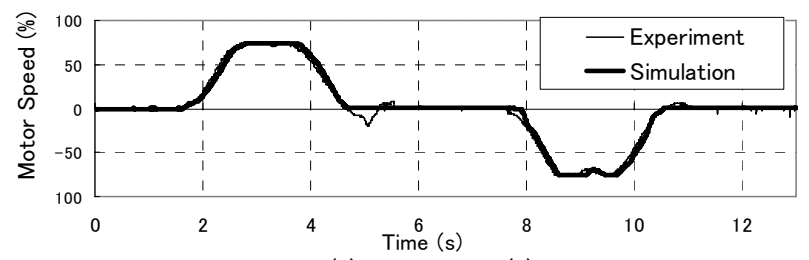

(a) Motor Speed (\%)

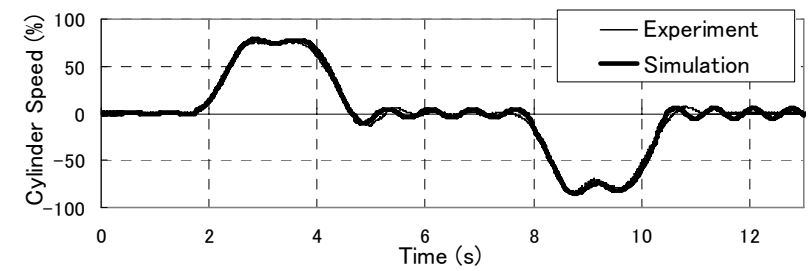

(b) Cylinder Speed (\%)

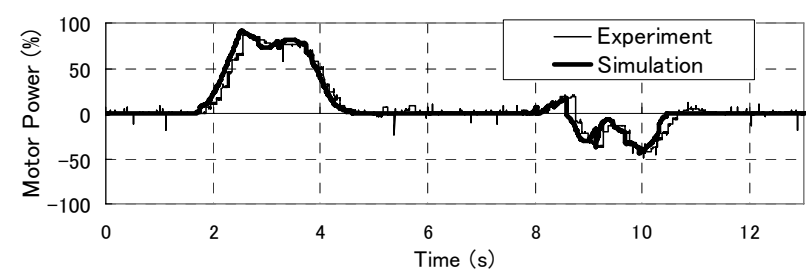

(c) Motor Power (\%)

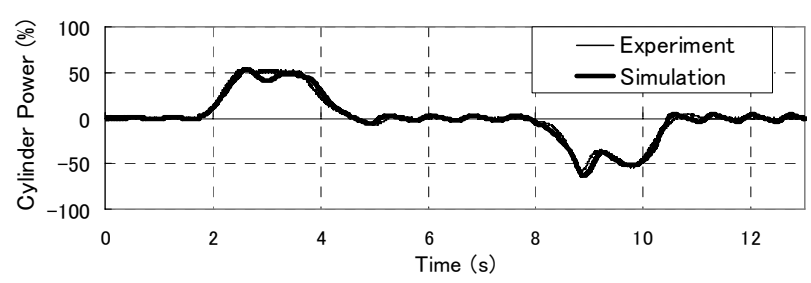

(d) Cylinder Speed (\%)

Fig.13 Experiment and simulation results of speed and power on cylinder and motor

\section{$4 \cdot 2$ システム動力評価および燃費評価}

実作業時の動力評価の例として, 図 14 に油圧ショベルの代表作業の 1 つである掘削積み込み作業のアクチュエ 一タ動力の性能評価結果を示す. 操作はブーム, アーム, バケット, 旋回の 4 アクチュエータの複合操作である. 従来システムとの比較のために, ハイブリッドシステムではアクチュエータ駆動電動機の入力電力の総和, 従来 システムでは駆動油圧ポンプの出力動力をアクチュエータ投入動力として比較している. ハイブリッドシステム では，特にアクチュエータ出力（作業有効出力）の低い作業後半に大幅な投入動力低減が図られており，狙いと する油圧低出力時の油圧配分ロスが低減できていることがわかる．ただし，作業前半では急操作時の電動機の加 速や掘削中の低速, 高負荷領域での電動機効率の低下などにより, 一部で従来油圧システムよりも悪い部分も出 
ている. 図 15 にこの作業でのアクチュエータシステムのエネルギ収支を示すが，この作業では従来油圧システム に対し約 45\%の動力低減が図られている. 表中, 回生エネルギは各アクチュエータの回生エネルギの総和を示し ているが，この作業では動力回生の比率が低い結果となっている.これは，この作業が市街地でのショベルの稼 動を前提としたものであり, アクチュエータの操作速度が抑えられている領域が多いため, 回生動力の比率が低 いと考えられる．前提とする作業の内容によっては，回生動力の比率はこれより高くなる可能性がある.

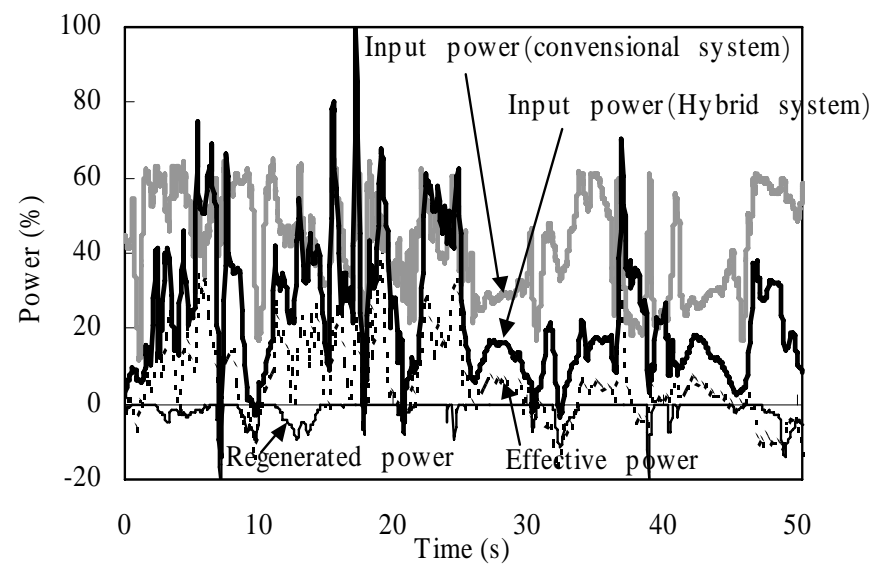

Fig.14 Actuator Power on Excavating and Loading

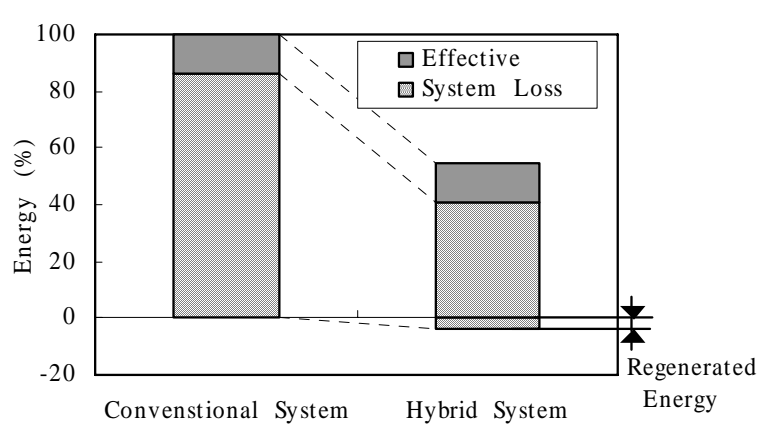

Fig.15 Energy Consumption of Actuator in Excavating and Loading

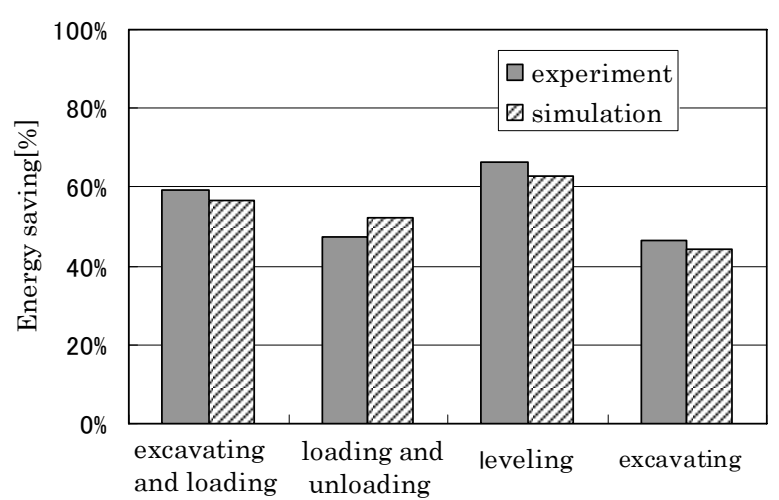

Fig.16 Experimental and simulation results of fuel energy saving effect on each operation mode

上記の掘削積み込み作業を含めて油圧ショベルの代表的な作業パターンでの燃費性能評価をトータルシミュレ ーションモデルにより評価し, 実機性能との比較検証を行った. 図 16 に各作業での従来機の作業燃費に対する八 イブリッドシステムでの燃費削減効果の実測結果とシミュレーション結果の比較を示寸．作業により，従来機と 比較し燃費削減効果に差はあるが，全ての作業において 40\%以上の燃費削減効果があることがわかった．シミュ レーション結果と性能実証機の実測結果の比較では, 燃費削減効果の評価がどの作業においても5\%以内の誤差 となっており, 狙い通りの性能が確保された。このことから, 本手法によるシミュレーション技術は, ハイブリ ッドショベルの燃費性能を精度よく事前予測できる, 実用的な技術であることが示された.

\section{5. 結 論}

電動油圧システム，およびハイブリッド動力源システムからなるハイブリッドショベルの開発において，八イ ブリッド動力源システムを構成する発電機, バッテリ，コンバータなどのパワーエレクトロニクス機器，アクチ ユエータシステムを構成する電動油圧機器, およびアタッチメントのリンクシステムからなるトータルシステム をモデル化したハイブリッドショベルのシミュレーションモデルを開発した．このモデルを用いて，アクチュエ ータ挙動および動力性能，燃費性能の性能評価を行うとともに，製作した性能実証機での実測により以下の結論 を得た。 
(1)ブームシステムにおける動力測定值とシミュレーション結果を比較したところ，両者はよく一致しており， 本シミュレーションモデルがアクチュエータ挙動および動力性能を評価する解析モデルとして妥当である ことを示した.

(2) 油圧ショベルの代表的な作業パターンについて，ハイブリッドショベルの燃費性能について，シミュレーシ ヨン結果と実測結果を比較したところ, 両者はよく一致しており，本シミュレーションによってハイブリッ ドショベルの燃費評価が可能であることを示した.

\section{謝辞}

本研究を進める上で貴重なご意見，ご指導をいただいた芦屋大学・藤川猛教授に感謝する．また，実験データ を提供していただいたコベルコ建機 (株) に感謝する. 本研究は新エネルギー・産業技術総合開発研究機構 (NEDO) の委託研究「ハイブリッド建設機械の研究開発」の研究費によって実施された.

\section{文献}

（1）井上宏昭，“ハイブリッド油圧ショベル”，建設の施工企画，No.707 (2009), pp.30-34.

（2）鹿児島昌之，“7t 級ハイブリッドショベルの開発”，建設の施工企画，No.707, (2009), pp.40-44.

(3) Shabana,A.A., "Flexible Multibody Dynamics:Review of Past and Recent Developments", Multibody System Dynamics, Vol. 1(1997), pp.189-222.

(4) Shabana,A.A., and Schwertassek,R., "Equivalance of the Floating Frame of Reference Approach and Finite Element Formulations” , International Journal of Nonlinear Mechanics, Vol.33, No.3 (1997), pp.417-432.

(5) Shabana,A.A., Hussien,H.A. and Escalona,J.L., "Application of the Absolute Nodal Coordinate Formulation to Large Rotation and Large Deformation Problems”, Transactions of ASME, Journal of Mechanical Design, Vol.120(1998), pp.188-195.

(6) Geradin,M. and Cardona,A., “Flexible Multibody Dynamics: A Finite Element Approach” , (2001), John Wiley\&Sons Inc.

(7) 今西悦二郎, 南條孝夫, 廣岡栄子, 井上喜夫, “油圧駆動による柔軟リンクシステムの動的シミュレーション”, 日 本機械学会論文集 C 編, Vol. 69, No.685 (2003), pp.2336-2343.

(8) 頭井洋, 井上喜夫, 井村章夫, 藤川猛, “リンク機構のシミュレーションに関する研究（第 1 報）” 日本機械学会 論文集 C 編, Vol. 52, No.483 (1986), pp.2814-2821.

(9) Lo,C., Luan,Y., Tate,E.D., and Zarger,T.H., “A Simulation Model for the Saturn VUE Green Line Hybrid Vehicle” , SAE Paper, No.2006-01-0441 (2006), pp.1-10. 